„Przekłady Literatur Słowiańskich”. T. 9, cz. 3

ISSN 2353-9763 (wersja elektroniczna)

DOI $10.31261 /$ PLS.2019.09.03.10

\title{
O przekładach literatury polskiej w Czechach i czeskiej w Polsce \\ Komentarz do bibliografii przekładów w 2016 i 2017 roku
}

\section{Commentary on the Bibliography of Translations of Czech Literature in Poland and Polish Literature in the Czech Republic in 2016 and 2017}

\author{
Jakob Altmann \\ iD https://orcid.org/0000-0001-7547-6036 \\ UNIVERSITY OF SILESIA IN KATOWICE \\ kuba.alt@interia.pl
}

Data zgłoszenia: 15.09 .2018 r. | Data akceptacji: 12.11.2018 r.

\begin{abstract}
Presented article is a recapitulation of visible tendencies in both Polish and Czech publishing markets with regard to publications of literary translations of Czech literature in Poland and Polish literature in the Czech Republic in 2016 and 2017. It presents the most important literary translations in each language pair, pointing out leading publishers and the most active translators in this area. Finally, the author outlines general paths along which the Polish literature translations in the Czech Republic and vice versa develop.
\end{abstract}

KEYWORDS | Czech literature in Poland, Polish literature in the Czech Republic, translations, translators 
Niniejszy wywód, będący swoistą kontynuacją opracowań z lat ubiegłych, ma na celu wskazanie niektórych czynników wpływających pośrednio i bezpośrednio na ukazanie się tłumaczeń utworów literatury polskiej w Czechach i czeskiej w Polsce. Przegląd ten będzie dotyczył tekstów opublikowanych w 2016 oraz 2017 roku i zestawionych odpowiednio w bibliografiach przekładów między tymi literaturami. Dokonano w nich podziału na następujące kategorie: poezja, proza, dramat i reportaż. Komentarz ten pozwoli ocenić potencjał czytelniczy literatury polskiej i czeskiej w Czechach i w Polsce, z uwzględnieniem jego rozwoju w porównaniu do lat ubiegłych.

Gdy przyjrzymy się tym zestawieniom, zwraca uwagę każdorazowo dysproporcja między liczbą tłumaczeń książkowych a czasopiśmienniczych, przy czym tych drugich jest znacznie mniej. Nie może to zaskakiwać, zważywszy na nieporównywalnie większą zauważalność ukazania się przekładu książki niż opublikowania drobnego przekładu w czasopiśmie, co zdają się dostrzegać także wydawcy. Istotny w tym kontekście jest między innymi dobór tłumaczonych autorów. W przypadku tych najbardziej znanych najczęściej publikowane są przekłady książkowe, natomiast teksty debiutujących w przekładzie poetów często ukazują się w ramach publikacji czasopiśmienniczych.

Zauważalny trend ostatnich dwóch lat to ciągle wzrastająca liczba przekładów literatury polskiej w Czechach, przy czym rok ubiegły stanowi pewnego rodzaju apogeum w tym względzie. Należy sobie więc zadać pytanie, czy ciągle aktualne jest stwierdzenie, że „zainteresowanie literaturą polską w Czechach wykaz[uje] znacznie gorsze statystyki”' . Gdy spojrzymy kilka albo nawet kilkanaście lat wstecz, zdanie to oczywiście jest uzasadnione. W odniesieniu do dwóch poprzednich lat należy je jednak zrewidować. Podczas gdy rok 2016 przyniósł porównywalną liczbę tłumaczeń obu literatur, w 2017 roku przekładów literatury polskiej w Czechach było znacznie więcej niż czeskiej w Polsce.

Ustosunkowując się do sytuacji przekładów obu literatur, należy jednak uwzględnić także charakter poszczególnych publikacji, a co za tym idzie ich znaczenie dla danego rynku czytelniczego. Więcej waży bowiem jakość książek i artykułów czasopiśmienniczych niż ich ilość. Istotny jest również charakter tłumaczonych utworów: po obu stronach są to takie gatunki, jak dramat, reportaż, powieść historyczna, literatura zaangażowana, groteskowa, fantastyczna, biograficzna, kryminalna czy kobieca. Do najważniejszych utworów ostatnich dwóch lat można zaliczyć zwłaszcza „polski” debiut młodej autorki Anny Bolavej - powieść psychologiczną Do tmy, za którą otrzymała najważniejszą

1 I. Mroczek, 2016: Komentarz do bibliografii przekładów literatury czeskiej w Polsce i literatury polskiej w Czechach w 2015 roku. „Przekłady Literatur Słowiańskich”, t. 7, cz. 2, s. 84 . 
czeską nagrodę literacką Magnesia Litera. Z literatury polskiej, która ukazała się w ostatnich dwóch latach w języku czeskim, szczególny rozgłos zyskało wydanie czeskiego przekładu Ksiag Jakubowych (Knihy Jakubovy) Olgi Tokarczuk. Mniejsze znaczenie należy natomiast przypisać publikacjom z literatury dziecięcej. W polskim wydaniu cieszy się ona szczególną popularnością wśród czeskich czytelników, o czym świadczy niemal tuzin opublikowanych w dwóch ostatnich latach książek dla dzieci, których autorami są m.in. Marcin Mortka czy Grzegorz Kasdepke.

Zarówno polska, jak i czeska beletrystyka cieszy się odpowiednio w Czechach i w Polsce niesłabnącym zainteresowaniem, i to głównie za sprawą kilku wydawnictw popularyzujących literatury obu krajów ościennych, których relacje literackie nadal wynikają głównie z własnego wyboru, „z własnej dojrzałości do recepcji określonych wartości strony drugiej”2. Spośród oficyn po polskiej stronie granicy należy wymienić głównie: Książkowe Klimaty, Wydawnictwo Afera (obydwa z siedzibą we Wrocławiu) oraz założone stosunkowo niedawno, w 2014 roku, Wydawnictwo Stara Szkoła. Są to oficyny, które wręcz preferują literaturę czeską, czyniąc ją jednym ze swoich podstawowych produktów. Jednocześnie są to jednak wydawnictwa niszowe, które zawdzięczają swoją egzystencję głównie zapałowi kilku bohemistów, a tłumaczenia finansowane są najczęściej $\mathrm{z}$ budżetu czeskiego Ministerstwa Kultury, co w jednym z wywiadów potwierdza również założycielka wydawnictwa Afera Julia Różewicz ${ }^{3}$.

Nakładem Książkowych Klimatów, wydawnictwa ukierunkowanego na literatury mniejsze Europy Środkowej, Wschodniej i Południowo-Wschodniej, ukazały się książki takich czeskich autorów, jak: Michal Ajvaz, Jaroslav Rudiš, Josef Škvorecký czy wspomniana już A. Bolavá, natomiast w Aferze opublikowano teksty Ivy Procházkovej, Petry Soukupovej, Pavla Šruta czy Petra Šabacha. Przywołana wcześniej autorka komentarza do bibliografii sprzed dwóch lat Izabela Mroczek ${ }^{4}$ pisała, że w 2016 roku miał się ukazać przekład jednej z najambitniejszych powieści czeskich ostatnich lat, a mianowicie Podróż na południe (Cesta na jih) autorstwa M. Ajvaza. Konstrukcja powieści opiera się - jak zazwyczaj u tego autora - na opowiadaniu w opowiadaniu oraz na stopniowym nakładaniu się poziomów rzeczywistości, co można odczytać jako metaforę naszego świata. Jako że w Podróży na południe język może wyrażać rzeczywistość lub sam być rzeczywistością, tłumacz stoi przed niezwykle trudnym

2 K. Kardyní-Pelikanová, 2009: Na marginesie postkolonialnych odczytań w relacjach polskiej i czeskiej literatury. „Porównania”, nr 6, s. 108.

3 M. Burnecka, 2016: W kapciach przez życie. Portal „Wroclife”. Dostępne w Internecie: https://wroclife.pl/nasze-miasto/kariera-biznes/w-kapciach-przez-zycie/ [dostęp: 10.09.2018].

4 I. Mroczek, 2016: Komentarz do bibliografii..., s. 85. 
wyzwaniem ${ }^{5}$. Translacji tej powieści podjął się pisarz, badacz i tłumacz literatury czeskiej (i wielu innych) Leszek Engelking, który już wcześniej zwrócił na siebie uwage publiczności literackiej przekładami dzieł znanych czeskich autorów, m.in. Danieli Hodrovej czy Jáchyma Topola ${ }^{6}$. Spośród nich na szczególną uwage zasługuje tłumaczenie sześciu powieści J. Topola (ukazały się one w przeciągu kilkunastu lat, wszystkie w XXI wieku) oraz obszerne opracowanie twórczości tego autora Nowe mity. Twórczość Jáchyma Topola.

Również książkę Národní třída (Aleja Narodowa) autora młodego pokolenia J. Rudiša można śmiało zaliczyć do kategorii twórczości ambitnej, do literatury zaangażowanej. Rozważane są w niej kwestie kapitalizmu, komunizmu, miłości i wolności, a więc tematy bliskie polskiemu czytelnikowi, z którymi w przekładzie zmaga się młoda tłumaczka i dramaturg Katarzyna Dudzic-Grabińska.

Trzecia najważniejsza publikacja Książkowych Klimatów z 2016 roku to Scherzo capriccioso. Wesoła fantazja na temat Dvoŕáka (Scherzo capriccioso: Veselý sen o Dvoŕákovi) autorstwa J. Škvoreckiego. Jest to próba dotarcia do okoliczności skomponowania przez wybitnego czeskiego kompozytora jego najważniejszego dzieła, czyli 9. symfonii zatytułowanej $Z$ nowego świata. Antonín Dvořák jest bliski J. Škvoreckiemu ze względu na artystyczną osobowość, dlatego odbiegająca od dotychczasowej twórczości autora powieść nie dziwi. Dla polskiego czytelnika jest ona interesująca ze względu na temat historyczny, wnoszący - dzięki przekładowi dokonanemu przez znanego i cenionego tłumacza literatury czeskiej i słowackiej Andrzeja Jagodzińskiego - różnorodność do polskiego obrazu literatury czeskiej.

W Książkowych Klimatach ukazała się w 2016 roku ponadto powieść o tematyce historycznej Zaginiony (Nezvěstný) autorstwa Egona Hostovskiego, pisarza zmarłego w latach 70. minionego wieku. Około 40 lat po pierwodruku (rok 1951) doczekała się swojej reedycji, jak również tłumaczenia. Akcja dzieła, która rozgrywa się w roku 1948, tuż po socjalistycznym przewrocie w Pradze, skupiona jest na postaci Erika Brunnera, żydowskiego intelektualisty, co z pewnością związane jest z pochodzeniem samego autora Zaginionego. Powieść również przełożył współpracujący z Książkowymi Klimatami A. Jagodziński. Zupełnie inny charakter ma Historia światła (Dějiny světla) Jana Němca. Jest to powieść o życiu fotografa Františka Drtikola. Jej przekładu podjęła się rozpoczynająca karierę Katarzyna Bańka, absolwentka Kulturoznawczych Studiów

5 Cytat samego autora pochodzący z notki o nim: http://www.czechlit.cz/cz/autor/ michal-ajvaz-cz/ [dostęp: 10.08.2018] (tłum. własne - J.A.).

6 Warto wspomnieć, że jest on rówieśnikiem jednego z najbardziej cenionych współczesnych polskich autorów, Andrzeja Stasiuka, którego J. Topol bardzo ceni i któremu jakoby zadedykował posłowie do przekładu najbardziej znanej powieści A. Stasiuka Jak zostałem pisarzem. Posłowie to zatytułował Supermarket bohaterów radzieckich. 
Slawistycznych w Warszawie. Czynnikiem decydującym o wyborze powieści było z pewnością doświadczenie tłumaczki jako fotografa.

Również w ubiegłym roku Książkowe Klimaty postanowiły wydać kilka godnych uwagi książek. Jest to w pierwszej kolejności przywołana już nagrodzona powieść psychologiczna Do tmy ( $W$ ciemność), napisana przez należącą do młodego pokolenia autorkę Bohumilę Adamovą, używającą pseudonimu artystycznego - Anna Bolavá. Jej dyskretna, a zarazem niepokojąca książka traktuje o zbieraczce ziół pochodzącej z południa Czech. Styl A. Bolavej jest oszczędny, cechują go krótkie zdania, co z kolei przywołuje na myśl powieść kryminalną. Tłumaczenia podjęła się w tym przypadku debiutująca tą powieścią Agata Wróbel, zwyciężczyni konkursu tłumaczeniowego im. Susanny Roth w 2016 roku, w ramach którego należało przetłumaczyć fragment książki czeskiej autorki.

W 2017 roku na łamach Książkowych Klimatów ukazał się również zbiór opowiadań Palinka. Prozy z Banatu (Pálenka. Prózy z Banátu), napisany jakoby przez męskiego odpowiednika A. Bolavej, tj. Matěja Hořavę. Urodził się on zaledwie rok wcześniej niż wspomniana autorka (w 1980 roku) i otrzymał — jako odkrycie roku 2015 - nagrodę Magnesia Litera. Książka M. Hořavy nosi również znamiona powieści psychologicznej (opowiadania koncentrują się na „rozpacz[y] człowieka uwięzionego w czyśćcu, w przedsionku, w którym wspomnienia przeszłego życia są bardziej namacalne od dnia dzisiejszego"7). Pokazuje nam to wyraźnie zamiłowanie tego wydawnictwa do prezentowania punktów widzenia młodego pokolenia pisarzy pochodzących z albo/i piszących o Europie Środkowej, Wschodniej i Południowo-Wschodniej (Banat). Tematyką opowiadań M. Hořavy są wspomnienia zawsze tego samego człowieka - bezimiennego głównego bohatera i jednocześnie narratora, który jest nauczycielem pracującym w gminie Waitzenried, czyli w rumuńskim wielokulturowym Banacie, gdzie w XIX wieku czescy emigranci założyli swoją osadę. Jest to nawiązanie do faktu historycznego, że w XIX wieku wielu mieszkańców $\mathrm{z}$ czeskich ziem wyemigrowało $\mathrm{z}$ różnych powodów (wiązało się to z polityką monarchii austro-węgierskiej i dotyczyło również innych krajów; motywacją była np. możliwość nabycia ziemi uprawnej za kilkakrotnie niższą cenę niż $\mathrm{w} \mathrm{kraju}^{8}$ ) do południowowschodniej granicy austriackiego imperium ${ }^{9}$. Dla

7 Por. O. Drewnowska, 2017: „Palinka. Prozy z Banatu” Matěj Hořava - recenzja. Dostępne w Internecie: http://okiemwielkiejsiostry.blogspot.com/2017/06/palinka-prozy -z-banatu-matej-horava.html [dostęp: 10.09.2018].

8 Por. M. Pavlásek, 2013: Clopodia česky zvaná Klopotín. Zapomenutá moravská kolonizace Banátu v multilokálním etnografickém bádání. „Český lid”, vol. 100 (2), s. 153.

9 Por. na przykład: Z.R. Nešpor, 1999: Banátští Češi jako potomci tolerančních sektářù. Religio. „Revue pro religionistiku”, vol. 7 (2), s. 129-143. 
znakomitej, debiutującej $^{10}$ tłumaczki, Anny Radwan-Żbikowskiej, szczególne

100 wyzwanie musiała stanowić mnogość dialektyzmów ( $\mathrm{z}$ „czeszczyzną banacką" na czele ${ }^{11}$ ), rozsianych po całym tekście i obecnych w ciągłej „samomowie” (termin „samomluva” został wprowadzony przez samego autora). Utrudniają one bowiem formalną ekwiwalencję, która jest istotna szczególnie wtedy, kiedy jakiś aspekt formalny jest jedną z dominant utworu literackiego. Tematyka Banatu jako materiał literacki rozsławiona została już wcześniej, i to głównie za sprawą niemieckiej noblistki Herty Müller, która we wsi Nitzkydorf w regionie Banatu Temeszwarskiego spędziła swoje dzieciństwo. Opisywała je jako pełne brudu, przemocy, alkoholu, niemoralności i beznadziejności ${ }^{12}$.

Nakładem wydawnictwa Afera ukazują się dzieła czeskich autorów mniej lub bardziej obecnych w świadomości literackiej Polaków, takich jak I. Procházková, P. Soukupová, P. Šrut czy P. Šabach. Pierwsza wymieniona twórczyni szczególnie znana jest jako autorka książek dla dzieci oraz scenarzystka. Z zamiłowania do teatru pochodzi - być może — również tytuł Mężczyzna na dnie (Vraždy v kruhu: Muž na dně). Jest to bowiem jej pierwszy kryminał, będący równocześnie wstępem do serialu telewizyjnego Zabójstwa w kręgu (Vraždy v kruhu). Powieść ta została dobrze przyjęta przez krytykę literacką zarówno w Czechach ${ }^{13}$, jak i w Polsce. Bywa zgodnie przedstawiana jako powieść kryminalna dorównująca swoim poziomem literackim najlepszym współczesnym szwedzkim kryminałom. Co ciekawe, z powieścią tą związane jest również powstanie serii Czeskie Krymi, w ramach której mają zostać zaprezentowane „najciekawsze współczesne powieści kryminalne zza południowej granicy"14 ${ }^{14}$ Wydawnictwo Afera przedstawia więc polskiemu czytelnikowi również konkretny gatunek literatury czeskiej, kryminał. Rok później, czyli w 2017 roku, zgodnie z zapowiedzią Afera wydała następną powieść kryminalną I. Procházkovej, zatytułowaną Roznegliżowanie

10 Według Wojciecha Stanisławskiego, autora artykułu zatytułowanego Cień o najdrobniejszych palcach nt. tejże książki. Dostępne w Internecie: https://wpolityce.pl/ kultura/354195-cien-o-najdrobniejszych-palcach [dostęp: 25.08.2018].

11 M.S. Rakova, 2017: Asymetrie stylové přiznakovosti výrazových prostředků v českém a bulharském překladu uměleckého textu. Dysertacja. Brno, Masarykova univerzita, Filozofická Fakulta, s. 116.

12 H.W. Pahlke, 2010: Herta-Müller-Ausstellung zeigte Autorin wie sie sich selbst gerne sieht. „Buchentdeckungen — Einige Gedanken zu Literatur und Philosophie”. Dostępne w Internecie: http://www.buchentdeckungen.de/blog/2010/11/27/herta-mueller -austellung-zeigte-autorin-wie-sie-sich-selbst-gerne-sieht/ [dostęp: 3.09.2018].

13 Por. K. Kubičková, 2014: Major stvořený pro Trojana je dobrý jako skandinávští detektivové. Idnes.cz, recenzja. Dostępne w Internecie: http://kultura.zpravy.idnes.cz/ vrazd-v-kruhu-maji-knizni-predlohu-dtr-/literatura.aspx?c=A141121_172532_lite ratura_ob [dostęp: 15.08.2018].

14 O książce Ivy Procházkovej Mężczyzna na dnie ze strony wydawnictwa: http://wy dawnictwoafera.pl/ksiazki/mezczyzna-na-dnie.html [dostęp: 15.08.2018]. 
(Dívky nalehko). Jest to kolejne spotkanie czytelników z komendantem Holiną z praskiego wydziału zabójstw. Roznegliżowanie stanowi powrót do prawdziwego kryminału, który potrafi zaciekawić czytelnika siłą dedukcji i metodycznym śledztwem. Przekonuje ponadto autentycznością swoich bohaterów „z krwi i kości"15. Ciekawym dla polskiego czytelnika elementem obcości jest środowisko społeczności wietnamskiej w Czechach, w samym środku stolicy, w którym powieść ta jest osadzona (znajduje to potwierdzenie w jednej z recenzji ${ }^{16}$ ). Poruszana jest $\mathrm{w}$ ten sposób także problematyka zakorzenienia w obcym, często nieprzyjaznym środowisku.

Tłumaczenia powieści Mężczyzna na dnie i Roznegliżowanie podjęła się sama założycielka wydawnictwa, J. Różewicz, wnuczka wybitnego twórcy Tadeusza Różewicza, nagrodzona w 2014 roku Nagrodą „Literatury na Świecie” za przekład powieści Petry Hůlovej Plastikowe M3 czyli czeska pornografia (Umělohmotný tř́pokoj). Odpowiada ona za większość przekładów literatury czeskiej $\mathrm{w}$ tym wydawnictwie. Jeden z recenzentów docenił, że w Mężczyźnie na dnie przyczyniła się ona $\mathrm{w}$ znacznym stopniu do „[s]tworz[enia] klimat[u] powieści” poprzez ,język i wrażenie, jakie wywiera na czytelniku” ${ }^{17}$. Podkreśla więc istotną rolę tłumacza przy tworzeniu świata przedstawionego, choć jest on na ogół „odpowiedzialny za kształt językowy, w jakim się [ta] rzeczywistość pojawia", a "autorowi przypisuje [się] trud stworzenia fikcyjnej rzeczywistości”18. W 2016 roku J. Różewicz przetłumaczyła także powieść Pod śniegiem (Pod sněhem) napisaną przez P. Soukupovą, autorkę, której początki literackie związane są, podobnie jak u I. Procházkovej, ze scenografią. Recenzenci opisują ją jako „specjalistkę od krojenia rodziny”, co pasuje zwłaszcza do powieści Pod śniegiem, gdzie podczas jazdy samochodem bohaterowie rozliczają się ze swoim dzieciństwem i przeszłością ${ }^{19}$. Tłumaczka i w tym przypadku musiała się wykazać całym swoim kunsztem, gdyż „powieść Soukupovej jest w jakiś sposób werystyczna i wyrażona bezkompromisowym współczesnym językiem, ale kryją

15 Por. R. Spitzer, 2017: Recenzja książki Ivy Procházkovej „Dívky nalehko”. Dostępne w Internecie: https://www.centrum-detektivky.cz/vse/divky-nalehko-iva-prochazkova [dostęp: 20.08.2018].

16 Por. M. Matyszczak, 2017: Wyższypoziom kryminału - Iva Procházková, Roznegliżowane. Dostępne w Internecie: https://www.kawiarenkakryminalna.pl/recenzje/874-wyzszy -poziom-kryminalu-iva-prochazkova-rozneglizowane [dostęp: 15.09.2018].

17 Por. recenzję książki Ivy Procházkovej Mężczyzna na dnie: http://www.rzeczgustu.com. $\mathrm{pl} / \mathrm{recenzje/ksiazki/mezczyzna-na-dnie} \mathrm{[dostęp:} \mathrm{15.08.2018].}$

18 Por. A. Legeżyńska, 1997: Tłumacz jako drugi autor - dziś. W: A. Nowicka-Jeżowa, D. Knysz-Tomaszewska, red.: Przekład literacki. Teoria - historia - współczesność. Warszawa, PWN, s. 42.

19 Informacja ze strony wydawnictwa: http://wydawnictwoafera.pl/ksiazki/pod-sniegiem. html [dostęp: 15.08.2018]. 
się w niej też metafory i symbole, które tworzą w umyśle czytelnika na długo zapadające w pamięć obrazy" ${ }^{20}$.

Trzeci z wymienionych autorów to P. Šrut, twórca popularnej serii o tzw. Niedoparkach (Lichožrouti). W ubiegłym roku ukazała się ostatnia jak dotąd książka z tej serii, zatytułowana Niedoparki na zawsze (Lichožrouti navždy). Przekładu wszystkich trzech tomów dokonała również J. Różewicz. Jest ona najlepszym przykładem tłumaczki będącej jednocześnie ambasadorką i popularyzatorką literatury, z której tłumaczy. Jako właścicielka wydawnictwa odpowiedzialna jest bowiem za podejmowanie wszelkich inicjatyw wydawniczych, jak choćby w przypadku Czeskiego Krymi.

Ostatnim wydawnictwem, którego przekłady literatury czeskiej będą tu omawiane, to założona cztery lata temu Stara Szkoła. Nakładem tej oficyny ukazały się w 2016 roku trzy książki i rok później pięć. Jedna z nich to będąca kontynuacją serii o szlacheckiej rodzinie Kostków Arystokratka w ukropie (Aristokratka ve varu) Evžena Bočka, autora najzabawniejszej książki roku 2012 (zgodnie z przeznaczeniem Nagrody Miloslava Švandrlíka) Ostatnia arystokratka (Poslední aristokratka). Rok 2017 przyniósł kolejną odsłonę opowieści o rodzinie Kostków, mianowicie Dziennik kasztelana (Deník kastelána). Co ciekawe, książka ta, wydana pod pseudonimem Jan Bittner, została przełożona już w roku 2008 i ma zgoła odmienny charakter niż pozostałe części serii. Podczas gdy pozostałe powieści traktujące o rodzinie Kostków są przede wszystkim kwintesencją czeskiego humoru, Dziennik kasztelana wywołuje raczej śmiech przez łzy.

Druga pozycja opublikowana w 2016 roku przez Starą Szkołę to z kolei „mistyczny porno-gastro thriller z XIX-wiecznej Pragi” (zgodnie z opisem wydawców) Młyn do mumii (Mlýn na mumie) autorstwa P. Stančíka. Według jednej z recenzji to „rozerotyzowana mieszanka groteski, farsy, kryminału, komedii i thrillera”, przez co w Polsce, w odróżnieniu od Czech (gdzie w 2015 roku otrzymała nagrodę Magnesia Litera), nie miałaby raczej szans na cenioną nagrodę literacką ${ }^{21}$. Trzeci przekład z literatury czeskiej wydany w 2016 roku przez Starą Szkołę to Świnki morskie (Morčata) autorstwa wybitnego współczesnego pisarza Ludvíka Vaculíka, który niedawno zmarł (w 2015 roku). Jest to ważna pozycja książkowa na polskim rynku wydawniczym, gdyż mamy do czynienia $\mathrm{z}$ autorem, który uchodził za symbol walki z radziecką polityką kulturową oraz nielegalną i niekonstytucyjną, w jego przekonaniu, cenzurą ${ }^{22}$. Świnki morskie są

20 K. Nos-Cybelius, 2016: Petra Soukupová - „Pod śniegiem” [recenzja premierowa]. Dostępne w Internecie: http://czepiamsieksiazek.pl/?p=2532 [dostęp: 15.08.2018].

21 Recenzja powieści Petra Stančíka „Młyn do mumii”. Dostępne w Internecie: http://www. owcazksiazka.pl/2017/01/petr-stancik-myn-do-mumii.html [dostęp: 16.09.2018].

22 Słynne jest w tym kontekście wystąpienie Vaculíka w ramach IV zjazdu Związku Czechosłowackich Pisarzy, który odbywał się w Pradze w dniach 27-29 lipca 1967 roku. 
zarazem debiutem literackim L. Vaculíka w Polsce, co w oczach wielu krytyków literackich jest wręcz powodem do wstydu ${ }^{23}$. Według czeskiego Słownika literatury czeskiej jest to krótka „powieść modelowa o absurdalności, wyobcowaniu i przyczynach ludzkiej agresywności”24, do której może człowieka doprowadzić presja społeczna.

Sprawcą pierwszego przekładu książki L. Vaculíka na język polski jest Mirosław Śmigielski, który odpowiada za wszystkie przekłady z języka czeskiego opublikowane w ubiegłych latach w Starej Szkole. Jest to bohemista młodego pokolenia, który — podobnie jak J. Różewicz — założył wydawnictwo specjalizujące się w rozpowszechnianiu czeskiej literatury, a dokładniej prozy, w Polsce. Jednym z powodów, dla których do tej pory polskie wydawnictwa nie sięgnęły po książki L. Vaculíka, jest z pewnością specyficzna, trudna do tłumaczenia czeszczyzna, charakteryzująca się nietradycyjnym szykiem słów, morawizmami i użyciem dialektu ${ }^{25}$. Według krytyka Romana Kandy L. Vaculík należy do grona niewielu wielkich autorów, mających swój własny styl, co wobec „większości współczesnej produkcji literackiej nie jest banalnym stwierdzeniem, lecz jedną z najcenniejszych wartości"26.

Poza wymienionymi należy jeszcze wspomnieć o przynajmniej dwóch publikacjach książkowych: po pierwsze, o trzeciej powieści mało znanego poety i prozaika czeskiego Marka Tomana Straszna nowina o okrutnym mordzie Szymona Abelesa (Veliká novina o hrozném mordu Šimona Abelese), przełożonej przez Andrzeja Babuchowskiego, oraz o filozoficzno-beletrystycznej książce Viktora Fischla Pieśń koguta (Kuropění), przetłumaczonej przez Krzysztofa Rejmera. Co warte zaznaczenia, obaj autorzy są żydowskiego pochodzenia, a to znajduje również odbicie w ich twórczości. Przekłady tych powieści ukazały się odpowiednio: w najstarszym polskim powojennym wydawnictwie o profilu literacko-humanistycznym Czytelnik i w wydawnictwie o profilu religijnym WAM.

Por. J. Lehár, A. Stich, J. Janáčková, J. Holý, red., 2008: Česká literatura od počátků $k$ dnešku. Praha, Nakladatelství Lidové noviny, s. 834.

23 Por. M. Fuzowski, 2011: Recenzja powieści Ludvíka Vaculíka „Świnki morskie”. „Newsweek” 9.08. Dostępne w Internecie: http://www.newsweek.pl/kultura/ksiazka/ swinki-morskie,35907,1,1.html [dostęp: 20.09.2018].

24 M. Zelinský, 1994: VACULÍK, Ludvík: Morčata. W: Slovník české prózy. Dostępne w Internecie: http://www.slovnikceskeliteratury.cz/showContent.jsp?docId=1592 [dostęp: 20.09.2018].

25 Por. T. Slavíková, 2010: Soubor fejetonů určených pro internetový server s mateřskou tematikou. Brno, Masarykova univerzita, Fakulta sociálních studií, s. 13 [praca licencjacka].

26 R. Kanda, 2015: Ludvík Vaculík uváděl jazyk do znění. „Deník Referendum”, 8.06 [dziennik internetowy]. Dostępne w Internecie: http://denikreferendum.cz/ clanek/20558-ludvik-vaculik-uvadel-jazyk-do-zneni [dostęp: 20.08.2018]. 
Na tle tłumaczeń pozycji książkowych zestawienie przekładów prozy i poezji czeskiej publikowanych w czasopismach wypada na ogół znacznie skromniej. W latach ubiegłych czeskie teksty w przekładzie na język polski ukazały się głównie w periodykach, takich jak „Fraza”, „Podgląd” i „Wyspa”. Publikowana jest przeważnie poezja, choć pojawiają się także teksty eseistyczne. Poruszająca problemy szeroko rozumianej kultury powszechnej „Fraza” postanowiła w 2016 roku wydać zbiór „zabawnie poetyckich historii i bajek o zwierzętach wszelkiego rodzaju, w których charakterach odzwierciedlają się również słabości współczesnych ludzi” ${ }^{27}$ pt. Pomysły miłośnika zwierząt Jaroslava Bočka, znanego dramaturga i filmoznawcy, oraz wybór wierszy Jiříego Červenki przetłumaczonych przez Karola Maliszewskiego. W roku 2017 na uwagę zasługuje przede wszystkim jeden z numerów „Literatury na Świecie”, gdyż dużą jego część stanowiły fragmenty kilku powieści świetnie znanego w Polsce J. Škvoreckiego.

W 2016 i 2017 roku polską literaturę w Czechach reprezentowało wielu czołowych autorów współczesnych, jak i kilku, którzy pisali głównie w XX wieku. Wśród nich należy wymienić: O. Tokarczuk, Zygmunta Miłoszewskiego, Sławomira Mrożka, Andrzeja Sapkowskiego, Mariusza Szczygła, L. Engelkinga, Stanisława Ignacego Witkiewicza i Ryszarda Kapuścińskiego. Po czeskiej stronie granicy wydawaniem przekładów polskich publikacji książkowych zajmują się m.in. Host - jedno z największych wydawnictw popularyzujących literaturę polską w Czechach, z którym związane jest również czasopismo o tej samej nazwie, oraz Dokořán - oficyna specjalizująca się w literaturze popularnonaukowej i fachowej, sięgająca również po wysokiej jakości beletrystykę i poezję $e^{28}$. W roku 2017 przekłady niezwykle popularnego w Czechach polskiego reportażu ukazały się natomiast w dużej mierze w słowackim wydawnictwie Absynt. W odróżnieniu od omawianych wcześniej polskich wydawnictw największe wydawnictwa czeskie, a więc Host i Dokořán, mają odmienny charakter, nie specjalizują się bowiem w publikowaniu literatury z jednego regionu czy kraju — na ich łamach ukazują się przekłady z wielu języków. Sprawia to, że - pomimo swojego niszowego charakteru - polskie wydawnictwa przyciągają większą uwagę czytelników i w efekcie uzyskują większe wsparcie finansowe na swoje przedsięwzięcia.

Za najważniejszą publikację ostatnich dwóch lat może z pewnością uchodzić wydanie czeskiego przekładu Ksiag Jakubowych O. Tokarczuk, dwa lata po ukazaniu się oryginału w Polsce. Owa potężna (bo prawie tysiącstronicowa) powieść historyczna, nagrodzona w 2015 roku najważniejszą polską nagrodą literacką Nike, pozwala czeskiemu czytelnikowi dociec, czym wyróżniała się

27 Oficjalny opis wydawcy oryginału Nápady milovníka zvírat (tłum. własne - J.A.).

28 Opis ze strony internetowej wydawnictwa Dokořán: https://www.dokoran.cz/?p=onas [dostęp: 20.08.2018]. 
dawna wieloetniczna Polska, choć jej zawiłość tematyczna jedynie w niewielkim stopniu przyczyni się do lepszego rozumienia „sąsiada”. Przekładu tego wielkiego dzieła podjął się tłumacz i znawca literatury polskiej Petr Vidlák. W wywiadzie udzielonym czasopismu „Host”, zatytułowanym Obtížnost překladu spočívá v míre souznění s autorem (Trudność przekładu polega na znalezieniu odpowiedniego stopnia harmonii z autorem), wypowiada się on na temat samej autorki, stanu i historii literackich stosunków polsko-czeskich, a także przekładu między tymi językami. Przyznaje między innymi, że największą przeszkodę stanowi, paradoksalnie, bliskość obu języków, przez którą tłumacz jest skłonny do upodobnienia swojego tekstu do oryginału pod względem językowym. Jedną z oznak tej przeszkody może być interferencja z polskiego szyku wyrazów ${ }^{29}$.

Jak widać, czytelnicy w Czechach upodobali sobie O. Tokarczuk, dlatego w ubiegłym roku ukazała się tam kolejna jej książka, zatytułowana Prowadź swój pług przez kości umarłych (Svůj vůz i pluh ved'přes kosti mrtvých), opisywana jako „thriller moralny”. Czesi zostają więc zapoznani z różnorodnością twórczości autorki - tym razem filozoficzno-moralna głębia spotyka się z lekkim gatunkiem powieści kryminalno-thrillerowej. W ten sposób mogą sobie wyrobić bardziej złożone zdanie na temat jej utworów. Przekładu tej dającej do myślenia książki, której akcja rozgrywa się blisko granicy polsko-czeskiej, w Kotlinie Kłodzkiej, dokonał także P. Vidlák.

Ważnym wydarzeniem literackim 2017 roku z punktu widzenia polskiej literatury w czeskim przekładzie jest aż pięć translacji opublikowanych w słowackim wydawnictwie Absynt, którego założeniem programowym jest wydawanie reportaży literackich, także dla czeskich czytelników, w ramach serii Prokletí reportéři - między innymi były to reportaże klasyków tego gatunku: Ryszarda Kapuścińskiego (Szachinszach; cz. Šáhinšáh) czy Katarzyny Boni (Ganbare! Warsztaty umierania; cz. Ganbare! Workshopy smrti). Gatunek reportażu, jak wiadomo, cieszy się ogromną popularnością w Polsce, co również dostrzegają tłumacze, literaturoznawcy i wydawnictwa publikujące w języku czeskim. Odzwierciedleniem tego szerokiego zainteresowania jest opublikowana w roku 2016 monografia zatytułowana Fenomén: Polská literární reportáž, gdzie przedstawiono tradycje polskiego reportażu literackiego i powody jego sukcesu, którego gatunek ten nie odniósł na czeskiej scenie literackiej. Wyjątkowość polskiego reportażu według autorów wspomnianej monografii polega na tym, że nie szuka sensacji, a opowiada pozornie zwykłe historie ${ }^{30}$.

29 Por. H. Řehulková, 2016: Obtižnost překladu spočívá v míre souznění s autorem. [Wywiad z tłumaczem Petrem Vidlákiem]. „Host”, nr 5, s. 3.

30 M. Benešová et al., eds., 2016: Fenomén: Polská literární reportáž. Praga, Karolinum Press, s. 7. 
Przykładem przetłumaczonego reportażu literackiego z ostatnich lat jest także

106 Zabójca z miasta moreli: Reportaże z Turcji (Vrah z města meruněk — Příběhy $z$ Turecka) autorstwa Witolda Szabłowskiego, reportażysty związanego z „Gazetą Wyborczą”. Na opublikowanie przekładu tego tematycznie niezwykle aktualnego reportażu, dokonanego przez Barborę Gregorovą, zdecydowało się wydawnictwo Dokořán - drugie pod względem liczby publikacji książkowych polskich tekstów. Zasługą tejże oficyny jest także wydanie książki Projekt: prawda (Projekt: pravda) Mariusza Szczygła, ważnej ze względu na wkład tego autora w pogłębianie stosunków polsko-czeskich. Tym razem reportażysta zaproponował czytelnikowi jednak nieco mniej przystępną formę, gdyż książka ta jest swoistym kolażem łączącym w sobie „miniatury Mariusza Szczygła z własnego i cudzego życia oraz powieść z 1959 roku Portret z pamięci zapomnianego dziś pisarza Stanisława Stanucha”31. Kolaż ten, składający się z trzech części, charakteryzuje się wysokim stopniem gry między autorem a światem przedstawionym. „Nie tylko reporter przeszukuje świat w poszukiwaniu zdań-kluczy. Czasem świat sam zgłasza się do reportera,

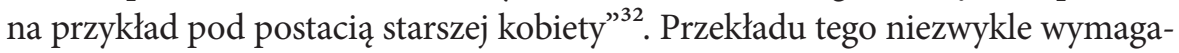
jącego utworu podjęła się zasłużona i bardzo doświadczona tłumaczka Helena Stachová, towarzysząca M. Szczygłowi przez całą jego karierę pisarską.

Z kolei wydawnictwo Host regularnie publikuje kolejne części trylogii kryminalnej autorstwa Zygmunta Miłoszewskiego, z prokuratorem Teodorem Szackim w roli głównej. W 2016 roku przełożony przez Terezę Pogodovą został Gniew (Hněv). Jak pokazują lata ubiegłe, czescy czytelnicy upodobali sobie twórczość tego wybitnego powieściopisarza, znanego na skalę europejską. Świadczą o tym opublikowana w roku 2015 powieść Nezaplatitelný (Bezcenny), a rok wcześniej Zrnko pravdy (Ziarno prawdy). Rok 2017 już nie przyniósł kolejnego przekładu książek Miłoszewskiego, na opublikowane niedawno Jak zawsze czeskim czytelnikom pozostało więc jeszcze poczekać.

Jak wspomniano, polska literatura dziecięca cieszy się w Czechach dużym zainteresowaniem. Świadczą o tym liczne przekłady dzieł tego gatunku w ostatnich latach. Rok 2016 przyniósł tłumaczenia aż trzech kolejnych części przygód Tappiego, głównej postaci książek dla dzieci napisanych przez M. Mortkę. Pracą tłumaczeniową podzielili się w tym przypadku znany głównie z tłumaczenia poezji Michael Alexa oraz autorka i tłumaczka B. Gregorová. Również w 2017 roku nie zabrakło przekładów polskiej literatury dziecięcej, jak choćby książki autorstwa Justyny Bednarek czy dwóch publikacji G. Kasdepke, jednego z najbardziej cenionych współczesnych autorów literatury dziecięcej.

31 Por. stronę internetową Instytutu Reportażu: http://instytutr.pl/pl/dowody-na-istnie nie-wydawnictwo/katalog/m-szczygiel-projekt-prawda/ [dostęp: 29.08.2018].

32 Ibidem. 
Spośród publikacji książkowych należy wspomnieć jeszcze o co najmniej trzech tytułach. Pierwszym z nich jest tomik wierszy Muzeum dětství a jiné básnè (Muzeum dzieciństwa) autorstwa L. Engelkinga, który jest dobrze znany również jako tłumacz. Zbiór ten tworzą teksty odwołujące się do dzieciństwa autora w mieście rodzinnym Bytom na Górnym Śląsku. Do nadania tomikowi właśnie tej nazwy skłoniło autora prawdziwe Muzeum Dzieciństwa w Edynburgu. Praca nad przekładem tego dzieła była dla Václava Buriana, nieżyjącego już poety, publicysty i polonisty, z pewnością niezwykle wymagająca ze względu na obcojęzyczne i dialektalne fragmenty ${ }^{33}$.

Z drugim tytułem związany jest wspomniany już M. Alexa, który w ubiegłych latach przetłumaczył najwięcej polskich tekstów opublikowanych w książkach lub czasopismach. Chodzi o bestsellerową powieść kryminalną zatytułowaną Pochłaniacz Katarzyny Bondy zwanej „królową kryminału”34. Prawdopodobnie ze względu na małą produktywność i nieidiomatyczność nazw wykonawców czynności w języku czeskim tłumacz zdecydował się na tytuł Dívka o pưlnoci, co jest odwołaniem do świata przedstawionego w powieści, w którym występuje piosenkarz i autor przeboju Dziewczyna z pólnocy.

Trzeci tytuł stanowi niemałe zaskoczenie: prawie 40 lat po ukazaniu się oryginału Vatzlav Sławomira Mrożka doczekał się swojej adaptacji i przekładu na język czeski, a dokonał go pochodzący z Ostrawy krytyk teatralny, dramaturg i tłumacz Ladislav Slíva. Zainteresowanie Mrożkiem nie ustało również w 2017 roku, kiedy opublikowany został zbiór jedenastu opowiadań Ti, co mě nesou ( $C i$, co mnie niosa) - tytułem tym opatrzone jest również jedno z opowiadań Mrożka. Wbrew oczekiwaniom nie przynosi on jednak wiele nowego czeskiemu czytelnikowi, jedynie odkrywa dlań dotąd nieznaną linię w twórczości Mrożka ${ }^{35}$. Za przekład w tym przypadku odpowiada H. Stachová.

Porównując okoliczności ukazywania się przekładów publikacji książkowych w obu krajach, należy zwrócić uwagę na dwa czynniki. Podczas gdy w Polsce mamy do czynienia $\mathrm{z}$ dwoma wydawnictwami specjalizującymi się niemal wyłącznie w literaturze czeskiej (Afera i Stara Szkoła), w Czechach brakuje

33 Por. J. Macháček, 2016: Leszek Engelking: Muzeum dětství a jiné básně. Dostępne w Internecie: http://protimluv.net/leszek-engelking-muzeum-detstvi-a-jine-basne/ [dostęp: 11.09.2018].

34 Taką peryfrazę autorce nadał dziennikarz „Newsweeka” Jacek Tomczuk, zob. J. Tomczuk, 2016: Katarzyna Bonda. Królowa kryminałów i dziewczyna z Hajnówki. „Newsweek”, 28.09. Dostępne w Internecie: http://www.newsweek.pl/kultura/ katarzyna-bonda-kim-jest-krolowa-kryminalow-z-hajnowki-,artykuly,397806,1.html [dostęp: 11.09.2018].

35 T. Dohňanský, 2017: Mrożek, Stawomir. Ti, co mě nesou. Dostępne w Internecie: http://www.iliteratura.cz/Clanek/39079/mrozek-sawomir-ti-co-me-nesou [dostęp: 15.09.2018]. 
oficyny, która stawiałaby tylko na literaturę polską, co utrudnia to $\mathrm{w}$ znacznym stopniu jej rozpowszechnianie i popularyzowanie. Przeciwdziałać temu próbuje na przykład Instytut Polski w Pradze, który z roku na rok aktualizuje „Výběr z knižních novinek”, czyli „Książkowe nowości”. W Polsce natomiast nie dość, że istnieją wydawnictwa publikujące wyłącznie literaturę czeską, to jeszcze w promowanie kultury i literatury czeskiej włączają się takie instytucje jak Czeskie Centrum w Warszawie. Kondycja rynków wydawniczych w obu krajach wpływa na sytuację tłumaczy: czeskie wydawnictwa publikujące polską literaturę, w odróżnieniu od polskich oficyn, nie utrzymują stałej współpracy z konkretnymi tłumaczami, co odbija się na rozpoznawalności i autorów, i tłumaczy.

Jeśli chodzi o rok ubiegły, w Czechach ukazały się jeszcze przynajmniej dwie książki, których wydanie nie mogło pozostać bez reakcji na czeskim rynku czytelniczym. Ze względu na sławę autora jest to w pierwszej kolejności książka ekscentrycznego S.I. Witkiewicza Nikotyna, alkohol, kokaina, peyotl, morfina, eter + appendix, przetłumaczona na język czeski skrótowo jako Narkotika przez Ondřeja Krochmalnego. Mamy tu do czynienia z niezwykle ważną pozycją ze względu na swój wymiar moralno-społeczny, ukryty na przykład w części Niemyte dusze, będącej jakoby (pesymistyczną) „mapą drogową po duszach Polaków" ${ }^{36}$, która ukazuje czeskiemu czytelnikowi literackie podejście do mentalności Polaków. Ze względu na swoją niezwykłą jak na poezję obszerność na uwagę zasługuje również dwujęzycznie skomponowana książka zmarłego przed dwudziestu laty Andrzeja Sulimy-Suryna Oto droga twego imienia (Toto je cesta tvého jména) w przekładzie dokonanym przez Davida Zelinkę. Sama forma wydawania wierszy w wersji dwujęzycznej stanowi część koncepcji przekładowej $\mathrm{i}$ jest również celem samym $\mathrm{w}$ sobie. W książce pomieszczono wiersze $\mathrm{z}$ trzech tomików tego znakomitego, choć mało znanego za życia poety: Posłaniec Słowa, Światło i Więc dołóż do ognia trochę miłości i ciszy.

Liczbę i jakość przekładów literatury polskiej prezentowanej w czeskich czasopismach można uznać za podobną, przy czym najważniejsze tytuły zajmujące się tą dziedziną to „A2”, „Dějiny a současnost”, „Listy”, „Souvislosti” i „Tvar”. Znajdziemy w nich przede wszystkim teksty liryczne, choć pojawiają się w nich także teksty prozaiczne, $\mathrm{w}$ tym reportaże. Ich autorami są tacy autorzy jak Adam Zagajewski, Bronka Nowicka i Kazimierz Brakoniecki, Stanisław Barańczak czy Ewa Lipska.

36 P. Mikołajczyk: „Nikotyna, alkohol, kokaina, peyotl, morfina, eter + appendix + niemyte dusze", Stanisław Ignacy Witkiewicz - recenzja ksiażki. Dostępne w Internecie: https://okonakulture.pl/2016/05/25/3992,nikotyna-alkohol-kokaina-peyotl-morfina -eter-appendix-niemyte-dusze-stanislaw-ignacy-witkiewicz-recenzja-ksiazki/ [dostęp: 20.09.2018]. 
„A2" to niezależny krytyczny dwutygodnik kulturalny w najszerszym tego słowa znaczeniu, a więc śledzący również aktualne wydarzenia społeczne i polityczne. Na uwagę zasługuje zwłaszcza ukazanie się w 2016 roku na jego łamach debiutu młodej poetki B. Nowickiej Nakarmić kamień, za który w tym samym roku autorka odebrała prestiżową nagrodę literacką Nike. Tłumaczenia większości publikacji, jak również książki zawierającej czterdzieści cztery małe poematy prozą młodej poetki, we wszystkich czasopismach literackich podjął się M. Alexa. Dotyczy to również czterech publikacji A. Zagajewskiego, w których czeski czytelnik może znaleźć jego cztery wymiary artystyczne: poetycki (Spróbuj opiewać okaleczony świat), eseistyczny (Męczennicy i komedianci czyli co zrobiła poezja wXX wieku), prozatorski i ten związany z pokoleniem Nowej Fali. Jego teksty ukazały się na łamach czasopisma literacko-kulturalnego „Souvislosti”, w numerze poświęconym amerykańsko-brytyjskiemu poecie T.S. Eliotowi i właśnie A. Zagajewskiemu, co można uznać za duże wyróżnienie. Godne uwagi jest ponadto ukazanie się czterech wierszy K. Brakonieckiego, w których istotną rolę odgrywa jego pochodzenie warmińsko-mazurskie, w związku z czym został w 2009 roku nagrodzony Literacką Nagrodą Warmii i Mazur. Są to wiersze zatytułowane Borussia, Głosy, Zuzanna B. oraz Wigilia, które zostały przetłumaczone - za wyjątkiem Borussii (wiersz ten został przetłumaczony przez Michala Špínę) - również przez M. Alexę. W ubiegłym roku najaktywniejsze, jeśli chodzi o publikowanie polskiej poezji w czeskim wydaniu, były czasopisma „Protimluv” i „Tvar”. Na łamach tego pierwszego ukazały się wiersze kilku znakomitych polskich poetów, takich jak Marek Bieńczyk, S. Barańczak, Halina Poświatowska czy Marcin Orliński, przy czym jedynie ten ostatni należy do młodego pokolenia. Może to wskazywać na pewne obawy związane z przekładami tekstów poetów mniej znanych czy sprawdzonych. „Tvar” z kolei wydał $\mathrm{w}$ jednym numerze opowiadanie (Siwy koń w plamy kare Weroniki Murek), reportaż (Wanna z kolumnadą. Reportaże o polskiej przestrzeni Filipa Springera) oraz wybór wierszy wielu autorów.

Reasumując, zwraca uwagę wysoki poziom oraz wielość gatunków tłumaczonych tekstów, co $\mathrm{z}$ kolei idzie $\mathrm{w}$ parze $\mathrm{z}$ czasem potrzebnym na realizację przekładów. Ze względu na niewielkie wsparcie, jakie otrzymują projekty związane $\mathrm{z}$ tłumaczeniem literatur mniejszych, w tym literatury polskiej w Czechach i literatury czeskiej w Polsce, trudno oczekiwać większej liczby tłumaczeń. Najważniejsze na rynku wydawniczym wydają się przedsięwzięcia takie, jak zakładanie wydawnictw specjalizujących się w literaturze sąsiedniego kraju, co realizowane jest niestety tylko w Polsce (Afera i Stara Szkoła albo chociaż w dużym stopniu Książkowe Klimaty). Wymienione oficyny próbują pokazywać nie tylko „czeskość” literatury czeskiej, lecz także jej uniwersalne wartości literackie. 
Na podstawie dokonanego przeglądu przekładów czeskich tekstów ukazujących się w 2016 i 2017 roku w Polsce i polskich tekstów opublikowanych w tym samym czasie w Czechach można wyciągnąć kilka wniosków. Po pierwsze, polscy czytelnicy, tłumacze i wydawnictwa wykazują większe zainteresowanie czeską prozą, a poezja schodzi na dalszy plan, podczas gdy w Czechach teksty liryczne publikowane w książkach i czasopismach stanowią większość (np. wiersze L. Engelkinga, Piotra Pazińskiego, Renaty Putzlacher, Jerzego Kozarzewskiego, Antoniego Matuszkiewicza czy Urszuli Tom wydane w formie książkowej, oraz wiersze Tadeusza Dąbrowskiego, B. Nowickiej, A. Zagajewskiego z ostatnich dwudziestu lat, K. Brakonieckiego, S. Barańczaka czy E. Lipskiej wydane w czasopismach). Po drugie, w obu krajach wydawnictwa oraz tłumacze, a w konsekwencji również czytelnicy, sięgają równie chętnie po tematy historyczne (Księgi Jakubowe O. Tokarczuk, Aleja Narodowa J. Rudiša), literaturę zaangażowaną (np. Mała zagłada Anny Janko, Morfina Szczepana Twardocha, Nikotyna, alkohol, kokaina, peyotl, morfina, eter + appendix S.I. Witkiewicza, Ja, Olga Hepnarová Romana Cílka, Zaginiony E. Hostovskiego czy Świnki morskie L. Vaculíka), jak również kryminał (Do tmy A. Bolavej, Pochłaniacz K. Boni, seria Vraždy v kruhu I. Procházkovej). Autorzy, których przekłady ukazują się w obu krajach, należą do różnych pokoleń. Są to autorzy młodego pokolenia, a więc urodzeni po roku 1970, ale także tworzący już w tym czasie oraz urodzeni jeszcze w pierwszej połowie XX wieku. Wyróżnia ich to, że ich twórczość zarówno w kraju swojego pochodzenia, jak i wśród czytelników sekundarnych cieszy się dużą popularnością. Istotnym atutem polskiego rynku czeskich przekładów literackich jest ścisła współpraca tłumaczy z konkretnymi wydawnictwami. W wielu przypadkach są nawet ich właścicielami, co przyczynia się do większej rozpoznawalności zarówno tłumaczy, jak i autorów.

\section{Literatura}

Benešová M. et al., eds., 2016: Fenomén: Polská literární reportáž. Praga, Karolinum Press.

Kardyní-Pelikanová K., 2009: Na marginesie postkolonialnych odczytań w relacjach polskiej i czeskiej literatury. „Porównania”, nr 6.

Legeżyńska A., 1997: Tłumacz jako drugi autor — dziś. W: A. Nowicka-Jeżowa,

D. Knysz-Tomaszewska, red.: Przekład literacki. Teoria - historia - wspótczesność. Warszawa, PWN.

Lehár J., Stich A., Janáčková J., Holý J., red., 2008: Česká literatura od počátků $k$ dnešku. Praha, Nakladatelství Lidové noviny. 
Mroczek I., 2016: Komentarz do bibliografii przekładów literatury czeskiej w Polsce i literatury polskiej w Czechach w 2015 roku. „Przekłady Literatur Słowiańskich", t. 7, cz. 2, s. 83-90.

Nešpor Z.R., 1999: Banátští Češi jako potomci tolerančních sektářù. Religio. „Revue pro religionistiku”, vol. 7 (2), s. 129-143.

Pavlásek M., 2013: Clopodia česky zvaná Klopotín. Zapomenutá moravská kolonizace Banátu v multilokálním etnografickém bádání. „Český lid”, vol. 100 (2), s. $149-172$.

Rakova M.S., 2017: Asymetrie stylové př́znakovosti výrazových prostředků v českém a bulharském překladu uměleckého textu. Dysertacja. Brno, Masarykova univerzita, Filozofická Fakulta.

Řehulková H., 2016: Obtižnost prekladu spočivá v míre souznění s autorem. [Wywiad z tłumaczem Petrem Vidlákiem]. „Host”, nr 5.

Slavíková T., 2010: Soubor fejetonů určených pro internetový server s mateřskou tematikou. Brno, Masarykova univerzita, Fakulta sociálních studií. [Praca licencjacka].

\section{Źródła internetowe}

Burnecka M., 2016: W kapciach przez życie. Portal „Wroclife”. Dostępne w Internecie: https://wroclife.pl/nasze-miasto/kariera-biznes/w-kapciach-przez -zycie/ [dostęp: 10.09.2018].

Dohňanský T., 2017: Mrożek, Sławomir. Ti, co mě nesou. Dostępne w Internecie: http://www.iliteratura.cz/Clanek/39079/mrozek-sawomir-ti-co-me-nesou [dostęp: 15.09.2018].

Drewnowska O., 2017: „Palinka. Prozy z Banatu” Matěj Hořava - recenzja. Dostępne w Internecie: http://okiemwielkiejsiostry.blogspot.com/2017/06/ palinka-prozy-z-banatu-matej-horava.html [dostęp: 10.09.2018].

Fuzowski M., 2011: Recenzja powieści Ludvíka Vaculíka „Świnki morskie”. „Newsweek”, 9.08. Dostępne w Internecie: http://www.newsweek.pl/kultura/ ksiazka/swinki-morskie,35907,1,1.html [dostęp: 20.09.2018].

Kanda R., 2015: Ludvík Vaculík uváděl jazyk do znění. „Deník Referendum”, 8.06 [dziennik internetowy]. Dostępne w Internecie: http://denikrefe rendum.cz/clanek/20558-ludvik-vaculik-uvadel-jazyk-do-zneni [dostęp: 20.08.2018].

Kubíčková K., 2014: Major stvořený pro Trojana je dobrý jako skandinávští detektivové. Idnes.cz, recenzja. Dostępne w Internecie: http://kultura.zpr avy.idnes.cz/vrazd-v-kruhu-maji-knizni-predlohu-dtr-/literatura.asp $\mathrm{x} ? \mathrm{c}=\mathrm{A} 141121 \_172532 \_$literatura_ob [dostęp: 15.08.2018]. 
Michal Ajvaz [notka o autorze]. Dostępne w Internecie: http://www.czechlit.cz/ cz/autor/michal-ajvaz-cz/ [dostęp: 10.08.2018].

Mikołajczyk P., 2016: „Nikotyna, alkohol, kokaina, peyotl, morfina, eter + appendix + niemyte dusze", Stanisław Ignacy Witkiewicz - recenzja książki. Dostępne w Internecie: https://okonakulture.pl/2016/05/25/3992,nikotyna -alkohol-kokaina-peyotl-morfina-eter-appendix-niemyte-dusze-stanislaw -ignacy-witkiewicz-recenzja-ksiazki/ [dostęp: 20.09.2018].

Macháček J., 2016: Leszek Engelking: Muzeum dětství a jiné básně. Dostępne w Internecie: http://protimluv.net/leszek-engelking-muzeum-detstvi-a-jine -basne/ [dostęp: 11.09.2018].

Matyszczak M., 2017: Wyższy poziom kryminału - Iva Procházková, Roznegliżowane. Dostępne w Internecie: https://www.kawiarenkakryminalna.pl/ recenzje/874-wyzszy-poziom-kryminalu-iva-prochazkova-rozneglizowane [dostęp: 15.09.2018].

Nos-Cybelius K., 2016: Petra Soukupová - „Pod śniegiem” [recenzja premierowa]. Dostępne w Internecie: http://czepiamsieksiazek.pl/?p=2532 [dostęp: 15.08.2018].

[O książce Ivy Procházkovej Mężczyzna na dnie]. Dostępne w Internecie: http:// wydawnictwoafera.pl/ksiazki/mezczyzna-na-dnie.html [dostęp: 15.08.2018].

[O powieści Petry Soukupovej Pod śniegiem]. Dostępne w Internecie: http://wy dawnictwoafera.pl/ksiazki/pod-sniegiem.html [dostęp: 15.08.2018].

Pahlke H.W., 2010: Herta-Müller-Ausstellung zeigte Autorin wie sie sich selbst gerne sieht. „Buchentdeckungen - Einige Gedanken zu Literatur und Philosophie”. Dostępne w Internecie: http://www.buchentdeckungen.de/ blog/2010/11/27/herta-mueller-austellung-zeigte-autorin-wie-sie-sich -selbst-gerne-sieht/ [dostęp: 3.09.2018].

Recenzja książki Ivy Procházkovej „Mężczyzna na dnie”. Dostępne w Internecie: http://www.rzeczgustu.com.pl/recenzje/ksiazki/mezczyzna-na-dnie [dostęp: 15.08.2018].

Recenzja powieści Petra Stančíka „Młyn do mumii”. Dostępne w Internecie: http://www.owcazksiazka.pl/2017/01/petr-stancik-myn-do-mumii.html [dostęp: 16.09.2018].

Spitzer R., 2017: Recenzja książki Ivy Procházkovej „Dívky nalehko”. Dostępne w Internecie: https://www.centrum-detektivky.cz/vse/divky-nalehko-iva -prochazkova [dostęp: dostęp: 20.08.2018].

Stanisławski W., 2017: Cień o najdrobniejszych palcach. Wpolityce.pl, recenzja. Dostępne w Internecie: https://wpolityce.pl/kultura/354195-cien-o-najdrob niejszych-palcach [dostęp: 25.08.2018].

Strona internetowa Instytutu Reportażu: http://instytutr.pl/pl/dowody-na-istnie nie-wydawnictwo/katalog/m-szczygiel-projekt-prawda/ [dostęp: 29.08.2018]. 
Strona internetowa wydawnictwa Dokořán: https://www.dokoran.cz/?p=onas [dostęp: 20.08.2018].

Tomczuk J., 2016: Katarzyna Bonda. Królowa kryminałów i dziewczyna z Hajnówki. „Newsweek”, 28.09. Dostępne w Internecie: http://www.newsweek. pl/kultura/katarzyna-bonda-kim-jest-krolowa-kryminalow-z-hajnowki -,artykuly,397806,1.htm [dostęp: 11.09.2018].

Zelinský M., 1994: VACULÍK, Ludvík: Morčata. W: Slovník české prózy. Dostępne w Internecie: http://www.slovnikceskeliteratury.cz/showContent. jsp?docId=1592 [dostęp: 20.09.2018].

\section{Jakob Altmann}

\section{Komentáře k bibliografii překladů české literatury v Polsku a polské literatury v České republice v letech 2016 a 2017}

RESUMÉ | Tento komentár k bibliografii překladů české literatury v Polsku a polské literatury v České republice v letech 2016 a 2017 je rekapitulací pohybů na polském a českém vydavatelském trhu, spojených s publikací překladů české literatury v Polsku a polské literatury v České republice v letech 2016 a 2017. V rámci tohoto vývodu byly prezentovány nejdůležitějš́ literární překlady v každém z jazykových párů. V této souvislosti se uvedla nejvýznamnější nakladatelství a nejaktivnější překladatele vzhledem k míře jejich př́spívání ke zlepšování polsko-českých literárně-kulturních vztahů. Nakonec čtenářova pozornost byla věnována obecnému vývoji a situaci překladů české literatury v Polsku a polské literatury v České republice.

KLÍČOVÁ SLOVA | překlady české literatury v Polsku, překlady polské literatury v České republice, překladatelé české literatury v Polsku, překladatelé polské literatury v České republice

\section{Jakob Altmann}

\section{Commentary on the Bibliography of Translations of Czech Literature in Poland and Polish Literature in the Czech Republic in 2016 and 2017}

SUMMARY | The Commentary on the Bibliography of Literary Translations of Czech Literature in Poland and Polish Literature in Czech Republic in 2016 and 2017 is a recapitulation of events on the Polish and Czech publishing market, with regard to publications of literary translations of Czech literature in Poland and Polish literature in the Czech Republic in 2016 and 2017. This commentary presents the most important literary translations in each language pair, pointing out the most important publishers and the most active translators in view of the degree of their contribution to the improvement of Polish-Czech literary and cultural relations. Finally, the reader's attention is drawn to the general development of translations of Polish literature in the Czech Republic and Czech literature in Poland. 
KEYWORDS | translations of Czech literature in Poland, translations of Polish literature in the Czech Republic, translators of Czech literature in Poland, translators of Polish literature in the Czech Republic

JAKOB ALTMANN | mgr, doktorant w Zakładzie Teorii Literatury i Translacji w Instytucie Filologii Słowiańskiej Uniwersytetu Śląskiego w Katowicach. Absolwent bohemistyki i hispanistyki na Akademii Techniczno-Humanistycznej w Bielsku-Białej. Jako rodowity Niemiec bada niemiecką literaturę drugiej połowy XX wieku ze szczególnym uwzględnieniem literatury niemieckiej noblistki Herty Müller oraz jej polskich i czeskich przekładów, z tego zakresu otrzymał grant w konkursie PRELUDIUM 15. Jego zainteresowania naukowe skupiają się na zagadnieniach językoznawczych, widzianych w kontekście kulturowym. Jest autorem kilku artykułów obejmujących tematy przekładoznawcze i językoznawcze. Publikował m.in. w czasopismach „Przekłady Literatur Słowiańskich” i „Zora” oraz w jednym z tomów serii wydawniczej „Studia o Przekładzie”. Wygłosił referaty na kilku konferencjach krajowych i zagranicznych. 